\title{
Constraints, and Implications of Organic Farming in Bananas and Plantains Production Sustainability in Benin
}

\author{
Anicet G. Dassou1 ${ }^{1}$, Silvère Tovignan'2 ${ }^{2}$ Fifanou Vodouhè2, Gbèlidji T. Vodouhè ${ }^{3,4}$, \\ René Tokannou ${ }^{3}$, Gervais-Claude Assogba², Valentin Kindomihou' ${ }^{5}$, Léonard Afouda², \\ Aimé H. Bokonon-Ganta6, Simplice D. Vodouhè 4
}

${ }^{1}$ Laboratory of Biotechnology, Genetic Resources and Plant and Animal Breeding, National University of Sciences, Technologies, Engineering and Mathematics (UNSTIM), Dassa, Benin

${ }^{2}$ Laboratory of Economic and Social Dynamics Analysis, Faculty of Agronomy, University of Parakou (UP), Parakou, Benin

${ }^{3}$ West African Network for Ecological and Organic Agriculture (PABE), Cotonou, Benin

${ }^{4}$ School of Economy, Socio-Anthropology and Communication (EESAC), FSA, UAC, Abomey-Calavi, Benin

${ }^{5}$ Laboratory of Applied Ecology (LEA), Faculty of Agronomic Sciences (FSA), University of Abomey-Calavi (UAC), Cotonou, Benin

${ }^{6}$ Laboratory of Agricultural Entomology (LEAg), Faculty of Agronomic Sciences (FSA), University of Abomey-Calavi (UAC), Cotonou, Benin

Email: dassoua5@gmail.com

How to cite this paper: Dassou, A.G. Tovignan, S., Vodouhè, F., Vodouhè, G.T., Tokannou, R., Assogba, G.-C., Kindomihou, V., Afouda, L., Bokonon-Ganta, A.H. and Vodouhè, S.D. (2021) Constraints, and Implications of Organic Farming in Bananas and Plantains Production Sustainability in Benin. Agricultural Sciences, 12, 645-665. https://doi.org/10.4236/as.2021.126042

Received: May 10, 2021

Accepted: June 22, 2021

Published: June 25, 2021

Copyright $\odot 2021$ by author(s) and Scientific Research Publishing Inc. This work is licensed under the Creative Commons Attribution International License (CC BY 4.0).

http://creativecommons.org/licenses/by/4.0/ (c) (i) Open Access

\begin{abstract}
Bananas and plantains production is an important income source for millions of small farmers. The increased demand for bananas and plantains on national and international market would justify its value chain development. However, its value chain faces several constraints, of which production and marketing turn out to be the most important. This study aimed at determining and analyzing the constraints related to Bananas and Plantains value chain and showing the gaps between agroecological and agricultural practices used by farmers in southern Benin. Characterization was carried out on the seed production systems, agricultural practices, bananas and plantains production, fruit availability and commercialization constraints with farmers using individual and focus groups surveys. Bananas and plantains seedlings production and acquisition varied according to production areas. Their seedlings self-production was widespread in production areas and 26 cultivars have been identified as major. The availability of these cultivars varied across time and production areas. There were significant negative effects of agricultural practices on major banana pest's presence. Bananas and plantains production was limited by 12 factors, from which banana plants fall related to the wind, lack of financial support to irrigate banana fields, climate changes, no availability of cultivable
\end{abstract}


lands and low rainfall are revealed to be the most important. Regarding commercialization constraints, low sale prices and difficult access to markets were the most important. Better knowledge of bananas and plantains production systems would help to develop sustainable organic farming strategies to reduce the constraints identified.

\section{Keywords}

Bananas and Plantain, Seedling Production, Agricultural Practices, Constraints, Organic Farming

\section{Introduction}

In Benin, bananas and plantains' value chain is gradually developing as an important economic opportunity to stakeholders. Many food products derived from bananas and plantains are found in local and urban markets and are sold better than before [1]. However, these include improved plantain chips, banana cakes and banana wine. Currently products such as banana fruits are commonly found in people's diets. Despite the food and economic importance of this value chain, bananas and plantains are less available and scarce at given times of the year on the markets. This unavailability would undoubtedly be linked to the various production and marketing constraints.

Production and marketing are the main constraints undermining the development of banana and plantain value chain [2] [3]. Concerning production constraints, the most important is the premature fall of plants under violent wind, diseases and pests damages. These constraints considerably reduce more than half of production [4]. To solve these problems, research actions are essential to develop systems that are both inexpensive and effective to protect cultivated plants against climatic hazards. Natural repellents, made with local products such as neem seeds, have kept diseases and pests away from cultivated plants [5]. It is also fundamental to relay the results of previous studies, going beyond analysis in terms of returns. It is essential to adopt a more comprehensive approach to the economic and social benefits of agroecology with an increase in household income linked to savings achieved through the abandonment of chemical inputs and the diversification of production. Several agricultural practices are used by the farmers to reduce these constraints' effects [6].

Farmers use agricultural practices such as self-production of seeds, crop associations, crop rotation, irrigation, use of animal droppings to fertilize soils, and use of biopesticides to control pests and diseases. Irrigation is essential for the survival of bananas [7]. Irrigation combined with good soil fertilization greatly improves productivity and makes plants more vigorous and tolerant. In general, bananas are susceptible to diseases (Fusarium wilt, Sigatoka, Banana Bunchy Top Disease, etc.) and pests including the banana weevil and nematodes [8]. 
Many agricultural practices, in particular the increase in plant biodiversity such as cover plants [9] [10], associated crops [11] [12] [13] increase the abundance of predators which reduce damage to pests [14].

This study aimed at determining and analyzing the constraints related to the bananas and plantains value chain and showing the gaps between agroecological practices and agricultural practices used by farmers in southern Benin. Specifically, the study aimed at 1) determining and analyzing constraints related to seed management and production of bananas and plantains, 2) analyzing bananas and plantains seedling production systems, 3) identifying elite bananas and plantains cultivars and their availability across the time and markets, 4) identifying the gaps between agroecological practices and agricultural practices used by banana and plantains farmers, and 5) networking bananas and plantains farmers to improve their agricultural practices and to convert them in organic agriculture.

\section{Material and Methods}

\subsection{Study Site}

Data were collected from June to November 2019 in the large banana and plantain production area in southern Benin. The four most important bananas and plantains production districts were selected to carry out this study: Mono (Athiémé, Lokossa, Comè); Atlantique (Tori, Zè, Sèhouè, Ouègbo, Allada), Ouémé (Akpo-Missrété, Dangbo) and Plateau. There are 2 rainy seasons (a long season and a short season) and 2 dry seasons (a long dry season and a short dry season). The average annual rainfall was $1300 \mathrm{~mm}$ of water and the average annual temperature was $28^{\circ} \mathrm{C}$. The soils were mainly vertisols and clayey type, very rich in minerals and contribute to a better productivity of bananas and plantains in the region of Toffo. The regions of Mono and Ouémé have ferruginous and sandy soils and lowlands favorable to the production.

\subsection{Selection of Bananas and Plantains Farmers}

In each selected district, 10 villages with 6 farmers per village were selected for the survey. Within villages, firstly, a Key Informant Interview (KII) was granted to the village chief to explain the interest of the study to him and then he gives us the list of some bananas and plantains producers. Then, other bananas and plantains producers were identified asking farmers interviewed. Farmers included in the study owned at least 0.5 hectare of bananas and plantains fields in order to ensure the importance that this crop represents in their daily agricultural activities.

\subsection{Socio-Demographic Parameters}

Individual and focus group surveys were used to carry out this study. Focus group survey brought together a large number of farmers in each selected village. The first step of the study concerned the socio-demographic characteristics 
of farmers (such as age, sex, marital status and number of experience years). Next, farmers were asked on their knowledge of organic farming and whether they are willing to pay the costs associated with the organic certification process.

\subsection{Management of Banana and Plantain Seed Production Systems}

A characterization was carried out on the seed production systems of bananas and plantains in order to offer farmers the seed sustainable management. First, information was gathered on bananas and plantains seeds acquiring methods such as seed donation, seed sharing, seed loan and seed self-production. Next, types of bananas and plantains seed production systems, especially technology based on seedlings from banana stem fragments commonly referred to as PIF [15] [16], were identified. Seed production systems using insecticides and those using biopesticides have been identified.

\subsection{Constraints and Problems Related to Production and Marketing}

During the individual survey, farmers identified all production and marketing constraints linked to bananas and plantains value chain. These constraints were ranked according to their importance and then updated in relation to previous studies [2]. During the focus group survey (on average 10 farmers per village) carried out in each selected village, producers listed in order of importance the problems that undermine the production and marketing of bananas and plantains.

\subsection{Identification of Elite Bananas and Plantains Cultivars and Their Availability across Districts and Time}

Based on the fact that a diversity of bananas and plantains cultivars existed in the study areas [2], farmers were asked to list the highly economical and productive elite cultivars in their districts. Then, the time and district availability of bunches of these cultivars were determined using scores. A score of 1 was attributed to cultivars with low bunch availability, score 2 for cultivars with moderate bunch availability and finally a score 3 for cultivars with high bunch availability.

\subsection{Identification of Agricultural Practices Used by Banana and Plantain Farmers and Diseases and Pests Presence in Plantations}

During the survey, farmers were asked to list the agricultural practices they use on their plantations. The agricultural practices listed were ranked in order of importance according to their quote frequency by farmers. The presence of the main diseases and pests of bananas and plantains has been determined in 45 farmers' fields. In each field, a field visit was organized in the morning of the day of the visit to identify diseases and pests. For the banana weevil, 20 pseudostem 
traps were used and placed randomly over the entire field for sampling [11] [12]. These traps were recorded 48 hours after installation to note the presence or absence of the pest in the field. Next, a few roots were taken from 20 randomly selected banana and plantain plants to observe galls and nematode damage spots in the laboratory in order to note the presence or absence of nematodes [17] [18]. The presence of symptoms (yellowing of the margins of the oldest leaves, wilting of the leaves with the constitution of a crown of dead leaves) of Fusarium sp. was sought and noted in each farmer's field. The presence of symptoms of Bunchy Top Banana Disease (BBTD) including plants that have turned into flowers.

\subsection{Gaps between Agricultural Practices Used by Farmers and Organic Farming Practices}

During focus group discussions, each agricultural practice was analyzed in a participatory manner with the farmers. Application modes of the practices have been detailed and then its deviation from organic farming practices is assessed using scores. A score of 1 (low level) means a small difference between the agricultural practice used and the practice of organic farming. The score 2 (mean level) means an average difference while the score 3 (high level) means a high difference between the agricultural practice used and the practice of organic farming.

\subsection{Data Analyses}

The Generalized Linear Model (GLM) distribution and logit link with the binomial family were carried out to determine the effects of agricultural practices and types of crop associations on the presence of the major pests and diseases of bananas and plantains. The Generalized Linear Model (GLM) distribution and logit link with the binomial family were also used to determine the relationship between the modes of production and acquisition of banana and plantain seedlings, the availability of different cultivars, means of farmer's communication and localities. Dendrograms were used to categorize the groups of banana production constraints. All the analyses were carried out in R [19] at the significant level of $5 \%$.

\section{Results}

\subsection{Socio-Economic and Demographic Characteristics of Farmers}

A total of 210 banana and plantains farmers were surveyed in the 4 zones of high production. Farmer's surveyed age varied from 39 to 47 years old with a mean age of 42 years. The majority of farmers were men especially in the Plateau district where no female banana/plantain farmers were surveyed. The most important presence of women (22.7\% of farmers) in bananas and plantains production was found in the Ouémé district. Bananas and plantains farmers were generally monogamous with $31 \%$ as the highest rate of polygamy observed in the Atlanti- 
que district. The ethnic groups represented were Goun (100\% of farmers of Ouémé and $81.8 \%$ for Plateau), Kotafon (72.50\% of farmers of Mono), Aizo (54\% of farmers of Atlantique) and Fon (21.7\% of farmers of Atlantique). The majority of the farmers surveyed were Christians (71.77\% of farmers), anemists (27.85\% of farmers) and very few Muslims ( $0.62 \%$ of farmers). The Mono district followed by the Atlantique had lands available for agriculture especially for the production of bananas and plantains. However, farmers of the Ouémé and Plateau have more professional experiences. The latter were less associated in cooperatives or groups of farmers for the bananas and plantains production. The majority of farmers in Mono ( $80 \%$ of farmers), Ouémé (100\% of farmers) and Plateau (100\% of farmers) have a good knowledge of organic banana production systems. Additionally, very few Atlantique farmers (10.9\% of farmers) knew the organic banana production. All the farmers surveyed were motivated to convert their production systems into organic production systems and the majority of them were ready to pay the costs of the certification process for their organic products. The main activities of surveyed farmers were agriculture $(91.25 \%$ of farmers) followed by animal breeding (47.05\% of farmers) and food processing (29.47\% of farmers) (Table 1 ).

\subsection{Acquisition and Production of Banana and Plantain Seedlings}

Production and acquisition of banana and plantain seedlings varied according to the production zones $(\mathrm{P}<0.00001)$. Self-production of banana and plantain seedlings was widespread in production areas (96\% of farmers). The purchase (51.83\% of farmers) and donation (48.35\% of farmers) of banana and plantain seedlings were also developed by some farmers. The production of bananas and plantains seedlings by the technology of plants resulting from stem fragments (named as PIF in French) were moderately used in the production area. Very few farmers inherited, collected and lent seeds of bananas. Few farmers have a good knowledge of organic banana seedling production using biopesticides (Figure 1).

\subsection{Banana and Plantain Cultivars Produced and Their Availability across the Time}

In total, the availability of 26 cultivars of bananas and plantains has been identified as major cultivars in the production areas (Figure 2). The availability of these cultivars varied across time and production areas $(\mathrm{P}<0.00001, \mathrm{Df}=27)$. In the Atlantique district, cultivars were highly available towards the end of the year. In Mono district, several cultivars were moderately available at the year starting and had become highly available throughout the year. In Ouémé district, all cultivars were poorly available in the first half of the year and had become highly available in the second half of the year. Finally, in the Plateau district, a few cultivars that were poorly available at the year starting became highly available from April to May (Figure 3). 
Table 1. Socio-economic and demographic characteristics of farmers.

\begin{tabular}{|c|c|c|c|c|c|}
\hline \multicolumn{2}{|l|}{ Parameters } & Atlantique & Mono & Ouémé & Plateau \\
\hline \multicolumn{2}{|l|}{ Mean age } & 41 & 39 & 47 & 42 \\
\hline \multirow{2}{*}{$\operatorname{Sex}(\%)$} & Female & 4.3 & 17.5 & 22.7 & - \\
\hline & Male & 95.7 & 82.5 & 77.3 & 100 \\
\hline \multirow{2}{*}{ Farmer's household situation (\%) } & Monogam & 68.5 & 72.5 & 79.6 & 81.8 \\
\hline & Polygam & 31.5 & 27.5 & 20.4 & 18.2 \\
\hline \multirow{6}{*}{ Ethnic groups (\%) } & Fon & 21.7 & 7.5 & - & 18.2 \\
\hline & Adja & 2.2 & 2.5 & - & - \\
\hline & Goun & 17.4 & - & 100 & 81.8 \\
\hline & Aizo (Ayizo) & 54.3 & - & - & - \\
\hline & Kotafon & 4.3 & 72.5 & - & - \\
\hline & Mina & - & 17.5 & - & - \\
\hline \multirow{3}{*}{ Religion (\%) } & Christian & 69.6 & 57.5 & 95.5 & 63.6 \\
\hline & Animist & 30.50 & 40 & 4.5 & 36.4 \\
\hline & Muslim & - & 2.5 & - & - \\
\hline \multicolumn{2}{|c|}{ Agricultural area available (hectare) } & 3.59 & 9.05 & 1.84 & 2.91 \\
\hline \multicolumn{2}{|c|}{ Agricultural area used (hectare) } & 2.63 & 8.63 & 1.77 & 2.64 \\
\hline \multicolumn{2}{|c|}{ Area occupied by bananas and plantains (hectare) } & 0.90 & 1.22 & 0.70 & 1.32 \\
\hline \multicolumn{2}{|c|}{ Seniority in banana and plantain production (years) } & 8 & 10 & 17 & 12 \\
\hline \multirow{2}{*}{ Banana farmers group/Cooperative (\%) } & Membership & 100 & 87.5 & 18.2 & 27.3 \\
\hline & No Membership & - & 12.5 & 81.8 & 72.7 \\
\hline \multirow{2}{*}{ Organic production system (\%) } & No knowledge & 89.1 & 20 & - & - \\
\hline & Knowledge & 10.9 & 80 & 100 & 100 \\
\hline \multirow{2}{*}{$\begin{array}{l}\text { Organic production of bananas and } \\
\text { plantains }\end{array}$} & Not motivated & - & - & - & - \\
\hline & Motivated & 100 & 100 & 100 & 100 \\
\hline \multicolumn{2}{|l|}{$\begin{array}{l}\text { Be ready to follow training } \\
\text { on the organic production process (\%) }\end{array}$} & 100 & 100 & 100 & 100 \\
\hline \multirow{2}{*}{$\begin{array}{l}\text { Pay the costs of the certification } \\
\text { of organic products (\%) }\end{array}$} & Not agree & 23.5 & 2.7 & 4.5 & 9.1 \\
\hline & Agree & 76.5 & 97.3 & 95.5 & 90.9 \\
\hline \multicolumn{2}{|l|}{ Agriculture } & 100 & 65 & 100 & 100 \\
\hline \multicolumn{2}{|l|}{ Animal breeding } & 8.7 & 25 & 81.8 & 72.7 \\
\hline \multicolumn{2}{|l|}{ Fishing/fish farming } & 2.2 & - & 13.66 & - \\
\hline \multicolumn{2}{|l|}{ Food processing } & 10.9 & 2.5 & 40.9 & 63.6 \\
\hline \multicolumn{2}{|l|}{ Small business/sales } & 8.7 & 27.5 & 59.1 & 27.3 \\
\hline \multicolumn{2}{|c|}{ Crafts (sewing, hairdressing, mechanics, etc.) } & 52.2 & 20 & 40.9 & 9.1 \\
\hline \multicolumn{2}{|c|}{ Government employee/private employee } & 6.5 & 12.5 & 4.5 & 9.1 \\
\hline
\end{tabular}




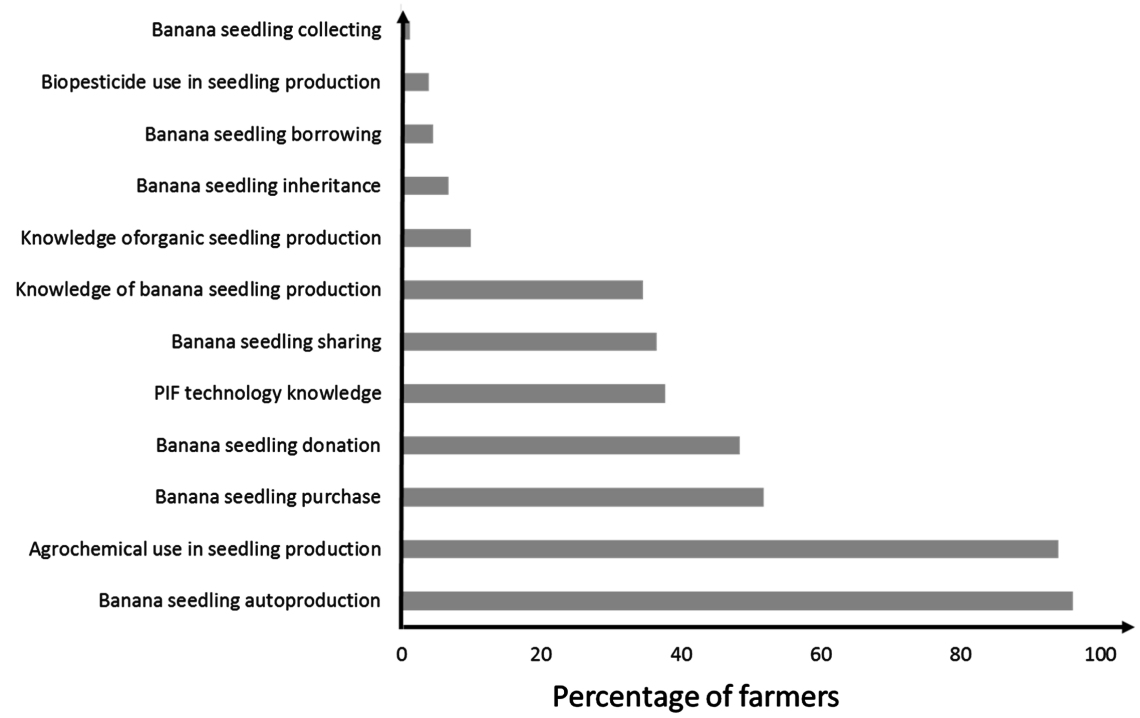

Figure 1. Modes of acquisition of banana seedlings.

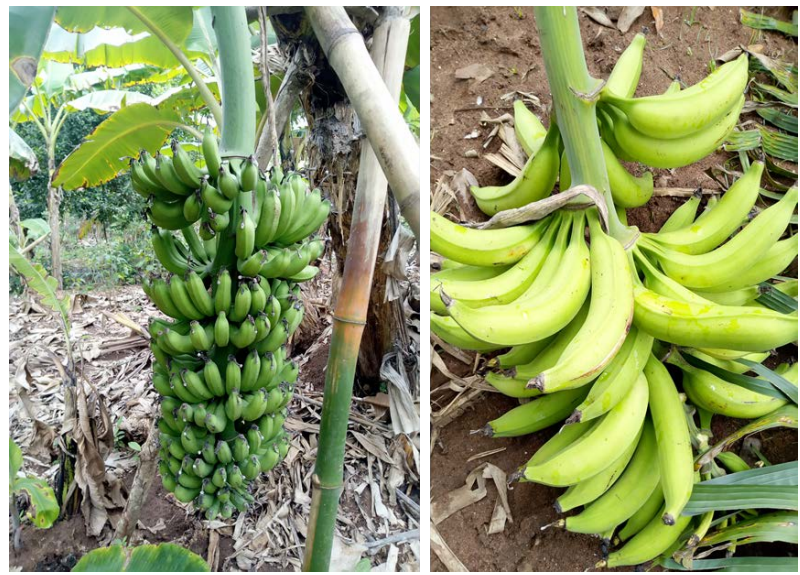

Figure 2. Banana cultivar Doheze on the left and Plantain cultivar Gnivlan on the right.

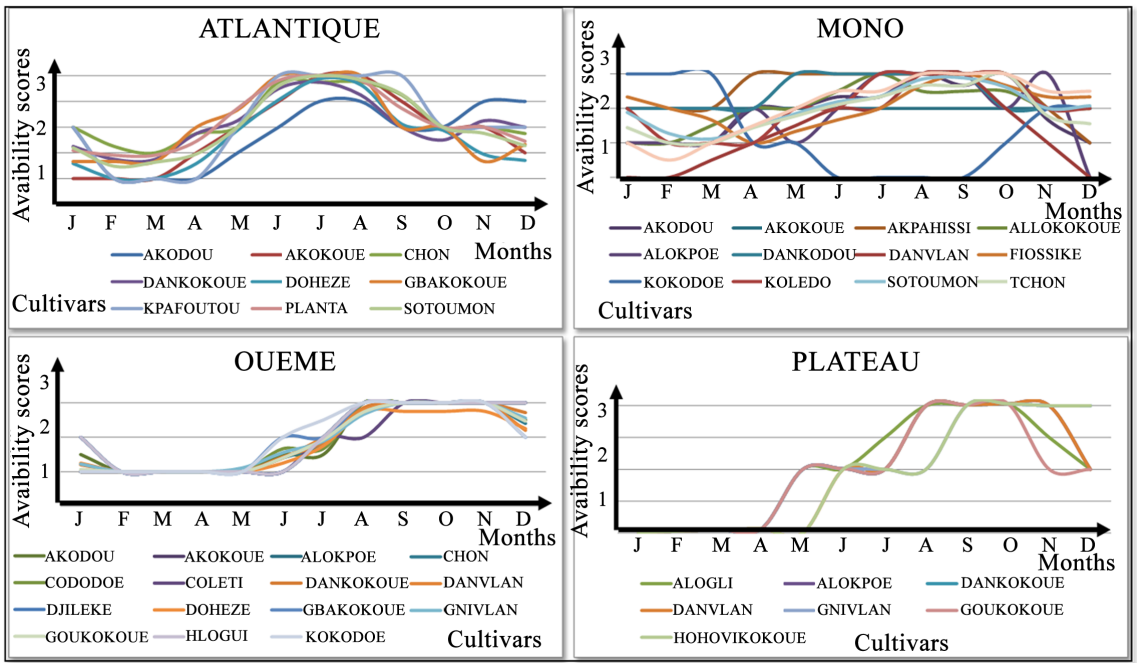

Figure 3. Banana and plantain varieties produced by district and their avaibility. 


\subsection{Agricultural Practices Used by Farmers in Bananas and Plantains Cropping Systems and Their Influence on Major Banana Pests}

Statistical analyzes revealed significant negative effects of agricultural practices on the presence of the major banana pests (Table 2). The most frequent agricultural practices used to face this issue were crop association $(89.30 \%$ of farmers, Table 3), mechanical destruction of diseased plants (51.07\% of farmers), banana plantations in shallows (30.10\% of farmers), crop rotation $(16.85 \%$ of farmers), compost use (9.65\% of farmers), poultry manure use $(7.92 \%$ of farmers) and herbicide use (6.82\% of farmers). Other agricultural practices were less frequently used by farmers ( $<5 \%$ of farmers) (Figure 4 ). The use of biopesticides, trap plants, composts, crop rotation and crop association have significant negative effects on the presence of the banana weevil. The use of manures and crop associations have significant negative effects on the presence of Fusarium $\mathrm{sp}$ while the use of biopesticides, irrigation and trap plants have significant negative effects on its presence. The use of biopesticides, agrochemicals, trap plants, crop rotation and crop association have significant negative effects on the presence of nematodes while cultivar resistance, irrigation, repellent plants, manure and shallow have significant positive effects. The use of trap plants, herbicides, shallows and the destruction of disease plants have significant negative effects on the presence of BBTV while the use of biopesticides and repellent plants have significant positive effects (Table 4).

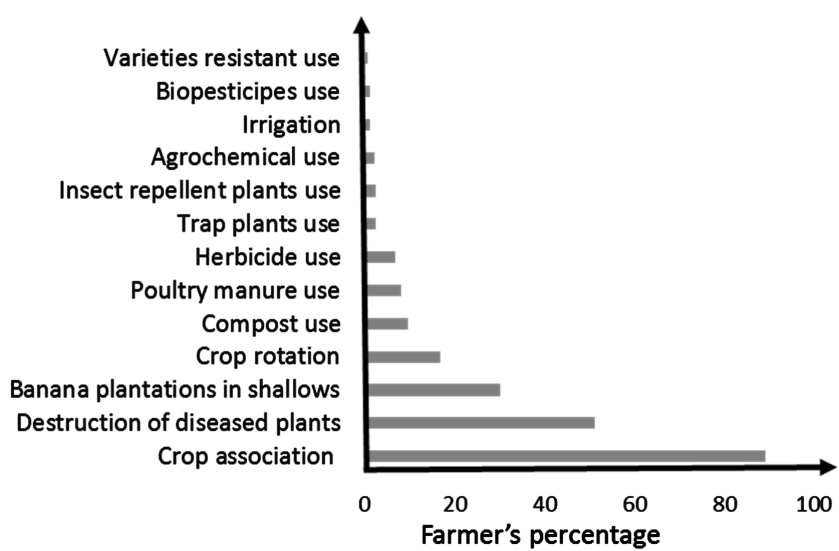

Figure 4. Agricultural practices used by banana and plantain farmer's.

Table 2. Effect of agricultural practices on the presence of major banana pests in the production zones.

\begin{tabular}{ccccc}
\hline Major banana pests & Estimates & Df & Deviance Resid & $\mathrm{P}(>\mid$ Chi $\mid)$ \\
\hline Banana weevil & -18.38 & 12 & 61.56 & $<0.00001$ \\
Nematodes & -0.51 & 12 & 25.76 & 0.0116 \\
Fusarium sp & -0.18 & 12 & 28.17 & 0.005217 \\
Banana Bunchy Top Virus & -0.91 & 12 & 31.52 & 0.001638 \\
\hline
\end{tabular}


Table 3. Farmer percentage cultivating crops associated to bananas and plantains in rainy season and in dry season.

\begin{tabular}{|c|c|c|c|}
\hline Associated crops & Scientific names & $\begin{array}{c}\text { Farmer percentage } \\
\text { cultivating in rainy season }\end{array}$ & $\begin{array}{l}\text { Farmer percentage } \\
\text { cultivating in dry season }\end{array}$ \\
\hline Plantains & Musa paradisiaca & 15.91 & 38.55 \\
\hline Bananas & Musa spp. & 6.51 & 30.12 \\
\hline Basilic (Tchiayo) & Ocimum gratissimum & 0.48 & 2.41 \\
\hline Pepper & Capsicum annuum & 3.86 & 2.41 \\
\hline Tomato & Solanum lycopersicum & 8.92 & 7.23 \\
\hline Okra & Abelmoschus esculentus & 0.72 & 1.20 \\
\hline Crin-crin & Corchorus olitorius & 0.48 & 1.20 \\
\hline African eggplant & Solanum macrocarpon & 0.96 & 3.61 \\
\hline Amaranth & Amaranthus spp. & 0.24 & 9.64 \\
\hline Pineapple & Ananas comosus & 1.69 & 0 \\
\hline Maize & Zea mays & 21.2 & 0 \\
\hline Cowpea & Vigna unguiculata & 8.92 & 0 \\
\hline Peanut & Arachis hypogaea & 5.54 & 0 \\
\hline Yam & Disocorea spp. & 1.69 & 0 \\
\hline Cassava & Manihot esculenta & 13.01 & 1.20 \\
\hline Palm & Elaeis guineensis & 3.61 & 1.20 \\
\hline Egussi & Citrullus lanatus & 0.24 & 0 \\
\hline Taro & Colocasia esculenta & 4.34 & 0 \\
\hline Sweet potato & Ipomoea batatas & 1.2 & 0 \\
\hline Lettuce & Lactuca sativa & 0.48 & 1.23 \\
\hline
\end{tabular}

Table 4. Effect of agricultural practices on the presence of major diseases and pests of banana and plantain. Values in the table are the probabilities of effects of agricultural practices on the presence of major pests and diseases. $\mathrm{P}<0.05$ means significant effects showing an influence of the agricultural practice on the presence of the pest or the disease and $\mathrm{P}>0.05$ means no significant effects showing no relation between the agricultural practice and the presence of the disease or the pest.

\begin{tabular}{|c|c|c|c|c|c|c|c|c|c|}
\hline \multirow[b]{2}{*}{ Practices } & \multirow[b]{2}{*}{ Df } & \multicolumn{2}{|c|}{ Banana weevil } & \multicolumn{2}{|c|}{ Fusarium sp } & \multicolumn{2}{|c|}{ Nematodes } & \multicolumn{2}{|c|}{ BBTV } \\
\hline & & Estimates & $\begin{array}{c}\operatorname{Pr} \\
(>\mathrm{Chi})\end{array}$ & Estimates & $\begin{array}{c}\operatorname{Pr} \\
(>\mathrm{Chi})\end{array}$ & Estimates & $\begin{array}{c}\text { Pr } \\
(>\mathrm{Chi})\end{array}$ & Estimates & $\begin{array}{c}\operatorname{Pr} \\
(>\mathrm{Chi})\end{array}$ \\
\hline $\begin{array}{c}\text { Resistance } \\
\text { plant }\end{array}$ & 79 & -16.45 & 0.222 & -0.14 & 0.892 & 1.35 & $0.020^{*}$ & -1.46 & 0.120 \\
\hline Biopesticides & 79 & -15.42 & $0.020^{*}$ & 2.29 & $0.019^{\star}$ & -17.35 & $0.017^{\star}$ & 18.16 & $0.001^{\star *}$ \\
\hline Irrigation & 79 & -15.39 & 0.425 & 14.95 & $0.005^{\star *}$ & 16.98 & $0.021^{\star}$ & 1.16 & 0.350 \\
\hline Agrochemical & 79 & -15.41 & 0.355 & 1.79 & 0.103 & -16.33 & $0.033^{\star}$ & 0.44 & 0.662 \\
\hline $\begin{array}{l}\text { Repellent } \\
\text { plants }\end{array}$ & 79 & -15.42 & 0.290 & 2.29 & $0.019^{*}$ & 0.08 & $0.001^{\star *}$ & 18.16 & $0.001^{* *}$ \\
\hline Trap plants & 79 & -0.90 & $0.048^{\star}$ & 1.37 & 0.150 & -17.35 & $0.017^{\star}$ & -17.24 & $0.022^{\star}$ \\
\hline Herbicides & 79 & -0.13 & 0.410 & 0.78 & 0.327 & 1.51 & 0.107 & -0.67 & $0.008^{\star *}$ \\
\hline
\end{tabular}




\begin{tabular}{|c|c|c|c|c|c|c|c|c|c|}
\hline Manure & 79 & 0.14 & 0.896 & -17.05 & $0.044^{\star}$ & 1.76 & $0.020^{*}$ & 0.91 & 0.244 \\
\hline Compost & 79 & -1.62 & $0.044^{\star}$ & -1.22 & 0.192 & -0.23 & 0.680 & -0.81 & 0.174 \\
\hline Rotation & 79 & -15.41 & $0.005^{* *}$ & 0.59 & 0.621 & -0.23 & $0.033^{*}$ & 0.44 & 0.662 \\
\hline Shallow & 79 & -15.42 & 0.29 & -15.98 & 0.178 & 18.0489 & $0.002^{* *}$ & -17.24 & $0.022^{*}$ \\
\hline $\begin{array}{c}\text { Crop } \\
\text { association }\end{array}$ & 79 & -16.48 & $0.001^{* *}$ & -17.05 & $0.044^{\star}$ & -1.029 & $0.007^{* *}$ & -0.29 & 0.689 \\
\hline $\begin{array}{c}\text { Diseased plant } \\
\text { destruction }\end{array}$ & 79 & -14.38 & 0.51 & -14.94 & $0.039^{*}$ & -16.28 & 0.135 & -17.05 & $0.0005^{\star * *}$ \\
\hline
\end{tabular}

\subsection{Soil Fertility and Pest Management in Banana and Plantain Systems}

Bananas and plantains farmers surveyed used chemical fertilizers and organic. In the Atlantique district, none of farmers surveyed used chemical fertilizers, but they used composts and poultry manure. In the other 3 districts, the majority of farmers used chemical fertilizers and a few used composts, poultry manure and cow dung (Table 5). Regarding the management of diseases and pests in banana and plantain cropping systems, farmers provided information on the knowledge and management of Banana Bunchy Top Disease (BBTD), phytophagous nematodes and banana weevil. Almost all farmers in Ouémé and Plateau and a few farmers in Atlantic and Mono have a good knowledge of the manifestations of BBTD and its symptoms. No farmer in the Atlantique and Mono districts knew about BBTD management methods. Very few farmers in the Ouémé and Plateau districts used Glyphosate (1\% of farmers in the Plateau), Sharp 480 (2.33\% of farmers of Ouémé) and Le Lagon (2.75\% of farmers of Ouémé) to fight BBTD. No organic product were used to fight BBTD. In the 4 districts, a few farmers knew how to identify the damage caused by the banana weevil. Farmers in the Atlantique (15.4\%) observed banana weevil damage in production systems up to $25 \%$ while the majority of farmers in all districts observed minor damage of up to $5 \%$. The majority of farmers in the 4 districts had a good knowledge of the symptoms and damage of phytophagous nematodes. The majority of Atlantique farmers used ashes (130 kg/hectare), ashes associated to motor oil (4 kg/hectare), ashes associated to oil neem (500 kg/hectare) and neem oil associated with neem leaf extracts (50 kg/hectare) (Table 6).

\subsection{Major Constraints Related to Banana and Plantain Production and Others Problems of the Value Chain}

Banana and plantain production was limited by 12 factors, the most important of which were banana plants fall related to the wind (88.65\% of farmers), the lack of financial support to irrigate banana fields ( $71.85 \%$ of farmers), climate changes (66.55\% of farmers), no availability of cultivable lands (60.32\% of farmers) and low rainfall ( $50.72 \%$ of farmers). Low quality of banana seedlings $(0.55 \%$ of farmers) was the least cited factor (Table 7). After production constraints, farmers 
Table 5. Conventional and organic products used in banana and plantain systems.

\begin{tabular}{ccccc}
\hline Parameters & Atlantique & Mono & Ouémé & Plateau \\
\hline & Chemical fertilizer use (Farmer's percentage) & \\
NPK & - & 100 & 87.5 & 100 \\
Urea & - & 100 & 87.5 & 100 \\
Potassium sulphate & - & 0 & 50 & 100 \\
\hline & Organic fertilizer use (Farmer's percentage) & \\
Compost & 50 & 0 & 100 & 0 \\
Poultry manure & 50 & - & 14.3 & 50 \\
Cow dung & - & 100 & - & - \\
\hline
\end{tabular}

Table 6. Pests and diseases management in banana and plantain systems.

\begin{tabular}{|c|c|c|c|c|c|}
\hline Parameters & & Atlantique & Mono & Ouémé & Plateau \\
\hline $\begin{array}{c}\text { Knowledge of manifestations of BBTD } \\
\text { (Banana Bunchy Top Disease) }\end{array}$ & & 4.3 & 5 & 100 & 72.7 \\
\hline \multicolumn{6}{|c|}{ Identification of BBTD symptoms (\%) } \\
\hline $\begin{array}{c}\text { Banana plants that are sterile or } \\
\text { produce inedible fruit }\end{array}$ & & 50 & 0 & 31.8 & 0 \\
\hline Bushy leaf top & & 50 & 0 & 0 & 0 \\
\hline Leaf edges turn yellow and curl upward & & 0 & 100 & 18.2 & 62.5 \\
\hline Narrow, erect and more or less short leaves & & 0 & 0 & 50 & 37.5 \\
\hline \multicolumn{6}{|c|}{ Quantity of agrochemicals used per hectare to manage BBTD (kg/hectare) } \\
\hline Griphosat & & - & - & - & 1 \\
\hline sharp 480 & & - & - & 2.33 & - \\
\hline Lagon & & - & - & 2.75 & - \\
\hline $\begin{array}{l}\text { Use of organic products for the management } \\
\text { of BBTD (\%) }\end{array}$ & & 0 & 0 & 0 & 0 \\
\hline \multirow[t]{2}{*}{ Knowledge of banana weevil damage } & & 28.3 & 2.5 & 45.5 & 27.3 \\
\hline & $25 \%$ & 15.4 & 0 & 0 & 0 \\
\hline \multirow[t]{2}{*}{ Average percentage of plant attacked } & $5 \%$ & 76.9 & 100 & 60 & 66.7 \\
\hline & $0 \%$ & 7.7 & 0 & 40 & 33.3 \\
\hline $\begin{array}{l}\text { Knowledge of the manifestations of } \\
\text { phytophagous banana nematodes }\end{array}$ & & 54.3 & 2.5 & 9.1 & 9.1 \\
\hline \multicolumn{6}{|c|}{ Manifestations of banana plant-feeding nematodes } \\
\hline Damage on banana roots & & 88 & 100 & 0 & 100 \\
\hline Premature fall of banana plants & & 64 & 100 & 100 & 0 \\
\hline Root nodules & & 60 & 0 & 0 & \\
\hline
\end{tabular}




\section{Continued}

Quantity of biological products used per hectare for the management of banana nematodes $(\mathrm{kg} / \mathrm{hectare})$

$\begin{array}{lcccc}\text { Ashes } & 130 & - & 119 & - \\ \text { Ashes and motor oil } & 4 & - & - & - \\ \text { Ashes and neem oil } & 500 & - & - & - \\ \text { oil and neem leaves extracts } & 50 & - & - & -\end{array}$

Table 7. Constraints related to banana and plantain production in the localities.

\begin{tabular}{|c|c|c|c|c|c|}
\hline Constraints & $\begin{array}{l}\text { Atlantique } \\
\text { (\%) }\end{array}$ & $\begin{array}{l}\text { Mono } \\
(\%)\end{array}$ & $\begin{array}{c}\text { Ouémé } \\
(\%)\end{array}$ & $\begin{array}{l}\text { Plateau } \\
(\%)\end{array}$ & $\begin{array}{c}\text { Mean } \\
(\%)\end{array}$ \\
\hline Banana plants fall related to the wind & 69.6 & 85 & 100 & 100 & 88.65 \\
\hline Lack of financial support to irrigate banana fields & 67.4 & 20 & 100 & 100 & 71.85 \\
\hline Climate Changes & 58.7 & 7.5 & 100 & 100 & 66.55 \\
\hline Non availability of cultivable land & 56.5 & 7.5 & 95.5 & 81.8 & 60.32 \\
\hline Low rainfall & 0 & 57.5 & 81.8 & 63.6 & 50.72 \\
\hline Soil poverty & 0 & 12.5 & 81.8 & 72.7 & 41.75 \\
\hline $\begin{array}{l}\text { Low production linked to BBTD } \\
\text { (Banana Bunchy Top Disease) }\end{array}$ & 0 & 0 & 100 & 63.6 & 40.9 \\
\hline Damage of other pests (banana weevil, nematodes...) & 13 & 25 & 36.4 & 45.5 & 29.97 \\
\hline Non availability of performing varieties & 34.8 & 0 & 13.6 & 36.4 & 21.20 \\
\hline Damage by monkeys & 0 & 0 & 18.2 & 36.4 & 13.65 \\
\hline Difficult access to banana seedlings & 10.9 & 2.5 & 4.5 & 9.1 & 6.27 \\
\hline Low quality of banana seedlings & 2.2 & 0 & 0 & 0 & 0.55 \\
\hline Others & 2.2 & 0 & 0 & 0 & 0.55 \\
\hline
\end{tabular}

frequently cited 15 major problems that hamper the development of bananas and plantains value chain (Table 8). The dendrogram realized made it possible to categorize the problems into 5 groups according to their importance. The first 3 groups were the most important. The first group was made up of problems such as difficult access to biofertilizers and biopesticides, difficult access to plant materials, high price of seedlings, and problems of plant fall. The 2nd group consisted only of climatic hazards. The third group was made up of low financial resources and difficult weed management. Regarding commercialization constraints (Table 9), low sale price (50.72\% of farmers) and difficult access to sales markets (37.02\% of farmers) were the most important. The short storage period (3.40\% of farmers), difficulty in accessing market information (3.90\% of farmers) were the least important constraints (Figure 5). The dendrogram produced made it possible to categorize the marketing constraints into 2 groups according to their importance (Figure 6). 
Cluster Dendrogram

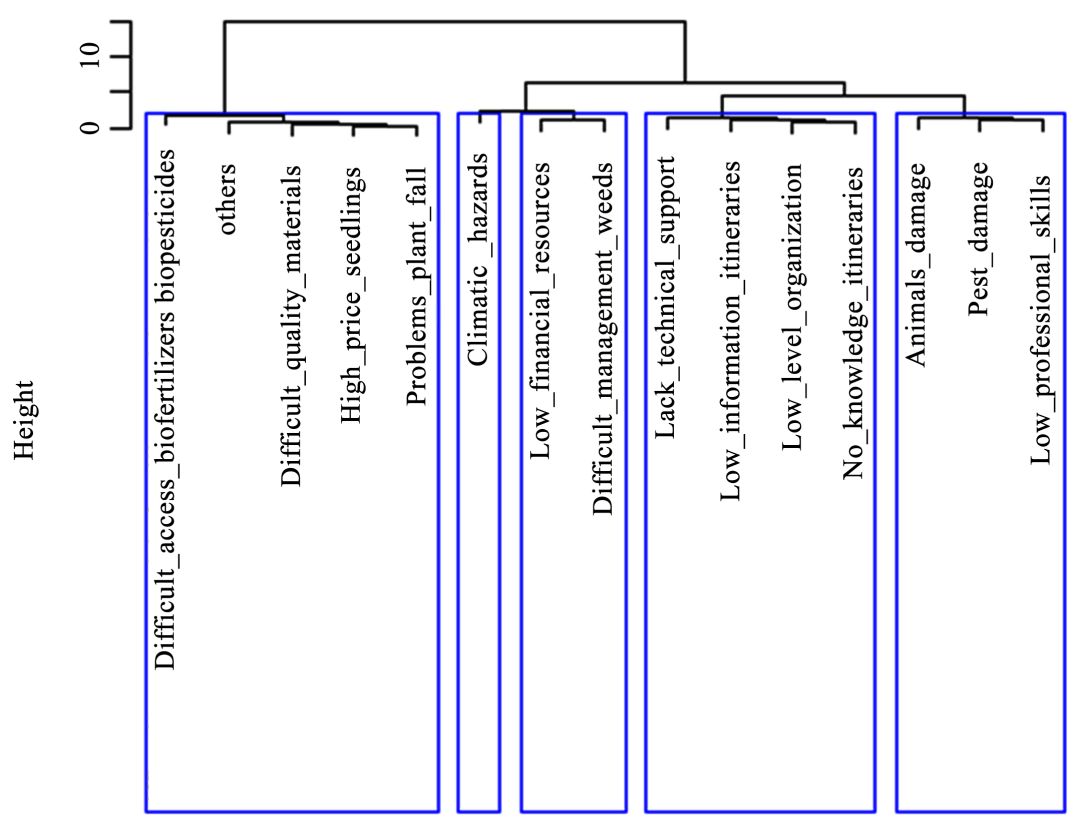

Farmer problem banana system

hclust (*, "ward.D”)

Figure 5. Hierarchization and categorization of banana and plantain production problems.

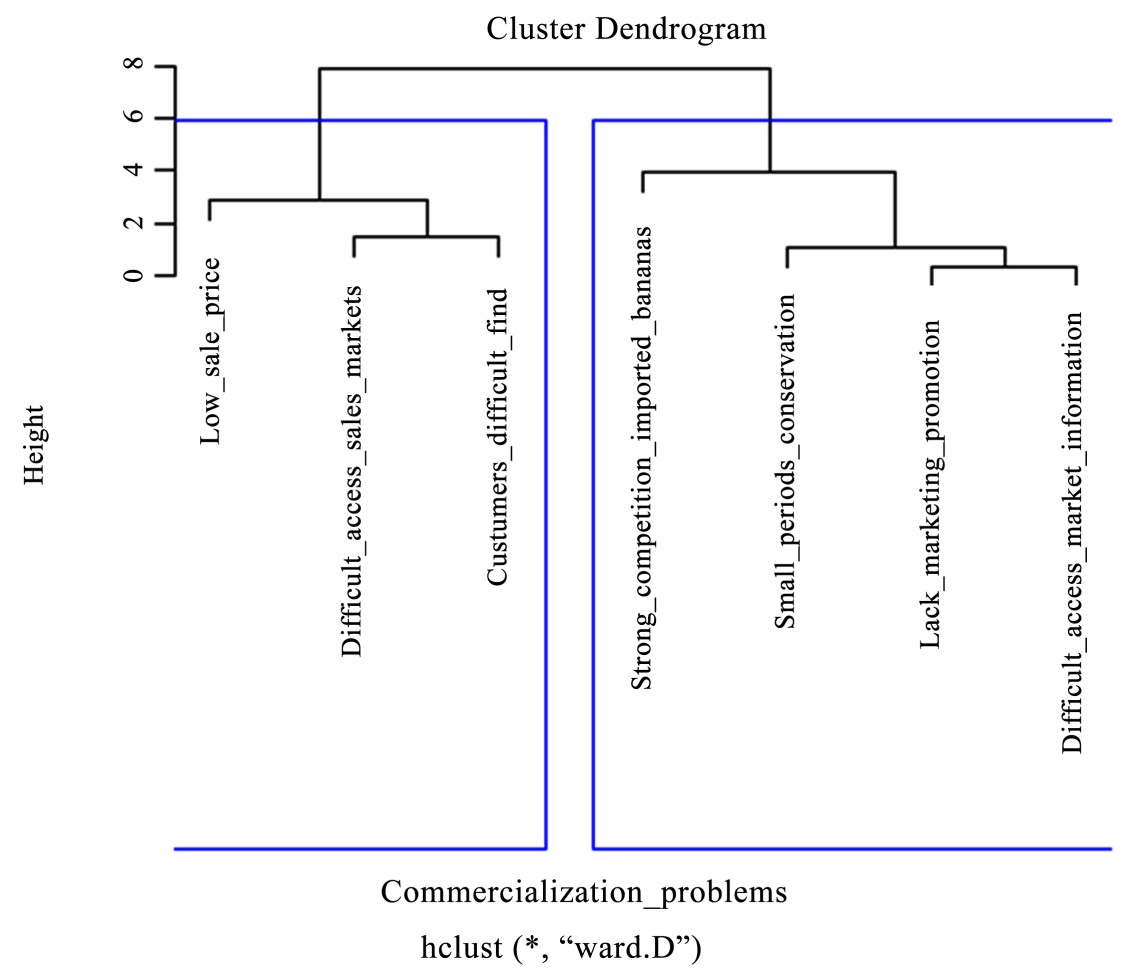

Figure 6. Hierarchization and categorization of banana and plantain commercialization problems. 
Table 8. Problems of banana and plantain production systems.

\begin{tabular}{lcccc}
\hline \multicolumn{1}{c}{ Constraints } & $\begin{array}{c}\text { Atlantique } \\
(\%)\end{array}$ & $\begin{array}{c}\text { Mono } \\
(\%)\end{array}$ & $\begin{array}{c}\text { Ouémé } \\
(\%)\end{array}$ & $\begin{array}{c}\text { Plateau } \\
(\%)\end{array}$ \\
\hline Banana tree fall related to the wind & 69.6 & 85 & 100 & 100 \\
Lack of financial support to irrigate banana fields & 67.4 & 20 & 100 & 100 \\
Climate Changes & 58.7 & 7.5 & 100 & 100 \\
Non availability of cultivable land & 56.5 & 7.5 & 95.5 & 81.8 \\
Low rainfall & 0 & 57.5 & 81.8 & 63.6 \\
Soil poverty & 0 & 12.5 & 81.8 & 72.7 \\
Low production linked to BBTD & 0 & 0 & 100 & 63.6 \\
(Banana Bunchy Top Disease) & 13 & 25 & 36.4 & 45.5 \\
Damage of other pests (banana weevil, nematodes...) & 34.8 & 0 & 13.6 & 36.4 \\
Non availability of performing varieties & 0 & 0 & 18.2 & 36.4 \\
Damage by monkeys & 10.9 & 2.5 & 4.5 & 9.1 \\
Difficult access to banana seedlings & 2.2 & 0 & 0 & 0 \\
Low quality of banana seedlings & 2.2 & 0 & 0 & 0 \\
\hline Others & & & & \\
\hline
\end{tabular}

\subsection{Gaps between Organic Agriculture Practices and Agricultural Practices Used by Farmers and Networking of Banana Farmers to Improve Their Agricultural Practices}

The farmers have a good knowledge of some organic farming practices such as organic fertilizers use, mulch use, biopesticides use, seed organic treatment and low knowledge for others practices (Table 10). The majority of farmers (100\%) could attend meetings and training while some farmers (80\%) could follow information on the agroecological practices on local radios. Regarding the use of phones and smartphones, $90 \%$ of the farmers surveyed had mobile phones while $65 \%$ of them could exchange SMS messages on innovate agroecological practices. Few farmers (10\%) with smartphones could exchange wathsapp messages on organic banana field management (Figure 7). There was a significant variation in the means of communication of farmers across the localities $(\mathrm{P}<0.00001$; Df $=12$ ).

\section{Discussion}

The present study has shown various modes of bananas and plantains seeds acquisition which are loan, donation and sharing. The most widely used procurement method was self-production, which could be explained by the regeneration of banana plants from the main plant. This method of acquiring seeds has been improved by farmers who use the banana stalk to produce ten to twenty seedlings by a technology called plants from stem fragments (PIF) [16] [20]. The PIF technology requires the use of agrochemicals to disinfect seed production systems. 


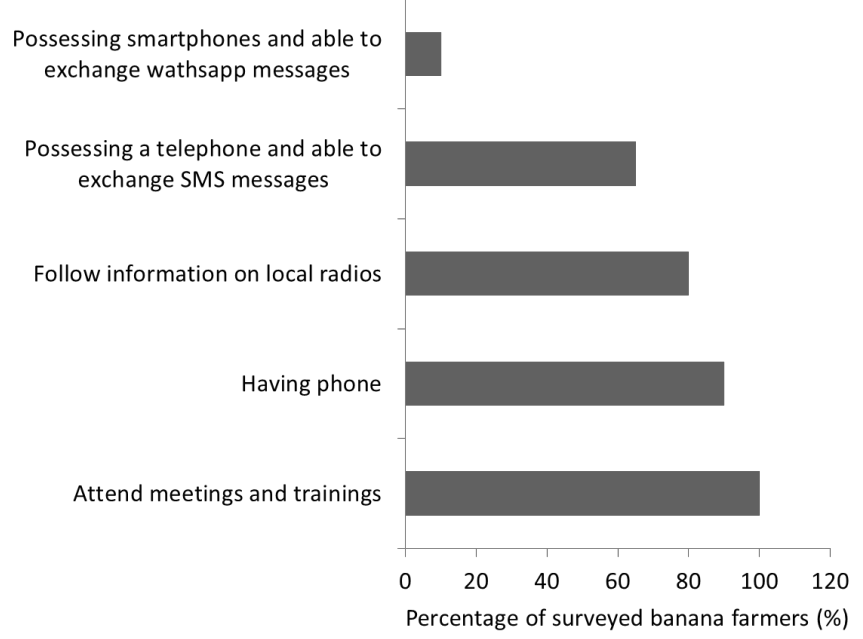

Figure 7. Means of communication of banana farmers on agroecological practices.

Table 9. Constraints related to the banana and plantain commercialization.

\begin{tabular}{|c|c|c|c|c|}
\hline Constraints & $\begin{array}{l}\text { Atlantique } \\
(\%)\end{array}$ & $\begin{array}{c}\text { Mono } \\
(\%)\end{array}$ & $\begin{array}{c}\text { Ouémé } \\
(\%)\end{array}$ & $\begin{array}{c}\text { Plateau } \\
(\%)\end{array}$ \\
\hline Low sale price & 91.30 & 52.50 & 31.80 & 27.30 \\
\hline Difficult access to sales markets & 28.30 & 42.50 & 31.80 & 45.50 \\
\hline $\begin{array}{l}\text { Lack of marketing and promotion of local bananas } \\
\text { and plantains }\end{array}$ & 13 & 2.50 & 4.50 & 9.10 \\
\hline Custumers difficult to find & 8.70 & 37.50 & 18.20 & 27.30 \\
\hline Difficult access to market information & 6.50 & 5 & 0 & 9.10 \\
\hline Strong competition with imported bananas and plantains & 4.30 & 5 & 63.60 & 9.10 \\
\hline Short periods of banana and plantain conservation & 0 & 0 & 13.60 & 0 \\
\hline
\end{tabular}

This agricultural practice does not respect organic farming principles and needs to be improved by the use of biopesticides such as neem oils.

Our results also showed the availability of 26 elite bananas and plantain cultivars in the production areas. This study focused on the most important cultivars unlike other studies which revealed a high diversity of cultivated bananas and plantains [2] [21]. Many cultivars of bananas and plantains are available during the rainy seasons thus showing that these production systems depend on the rains. Irrigation technics are very poorly developed in banana and plantain production systems. These agricultural practices combined with good soil fertilization could improve production systems and make bananas and plantains available all year round [22]. Unfortunately, few farmers invest in improving bananas and plantains production systems through innovative technologies. This result could be explained by the fact that in study area bananas and plantains have been neglected. Farmers produced them mainly for family consumption. But since market demand increased for these products they got more importance between farmer's crop choices. 
Table 10. Gaps between organic agriculture practices and agricultural practices used by farmers.

\begin{tabular}{|c|c|c|c|}
\hline $\begin{array}{l}\text { Organic } \\
\text { agriculture } \\
\text { practices }\end{array}$ & $\begin{array}{c}\text { Methods of application and } \\
\text { Contribution to the system in } \\
\text { organic and ecological agriculture }\end{array}$ & $\begin{array}{l}\text { Level of } \\
\text { involvement/knowledge } \\
\text { by farmers }\end{array}$ & $\begin{array}{l}\text { Response } \\
\text { percentage } \\
\text { of farmers }\end{array}$ \\
\hline \multirow{3}{*}{$\begin{array}{c}\text { Water } \\
\text { management }\end{array}$} & $\begin{array}{l}\text { Microbiological, chemical and } \\
\text { physical studies should be } \\
\text { performed to ensure that the } \\
\text { water used is clean, whether } \\
\text { it comes from a river } \\
\text { or an uncontaminated source }\end{array}$ & Low & $2 \%$ \\
\hline & $\begin{array}{l}\text { Keep tanks or water reservoirs } \\
\text { clean, avoiding contamination }\end{array}$ & Low & $2 \%$ \\
\hline & $\begin{array}{l}\text { The use of chlorine is the most } \\
\text { common method of ensuring the } \\
\text { bacteriological quality of water }\end{array}$ & Low & $2 \%$ \\
\hline \multirow{5}{*}{$\begin{array}{c}\text { Soil } \\
\text { management }\end{array}$} & $\begin{array}{l}\text { Choose for planting soils free } \\
\text { from pests (nematodes, banana } \\
\text { weevil, Cercospriosis, Fusarium, } \\
\text { banana bunchy top disease) } \\
\text { that affect bananas }\end{array}$ & Mean & $52 \%$ \\
\hline & $\begin{array}{l}\text { Soils for bananas should be loose, } \\
\text { deep and well-drained, with } \\
\text { good organic matter content } \\
\text { and good moisture retention }\end{array}$ & Low & $16 \%$ \\
\hline & $\begin{array}{l}\text { Adequate drainage to allow } \\
\text { the evacuation of surface } \\
\text { and underground water }\end{array}$ & Low & $5 \%$ \\
\hline & $\begin{array}{l}\text { Special treatment is required } \\
\text { for soils with high pH due to } \\
\text { high salt concentrations from } \\
\text { excessive chemical fertilization } \\
\text { in previous crops }\end{array}$ & Low & $6 \%$ \\
\hline & $\begin{array}{l}\text { Use of dead covers (mulch) to } \\
\text { avoid losing soil through runoff }\end{array}$ & High & $80 \%$ \\
\hline \multirow{2}{*}{$\begin{array}{l}\text { Soil fertilization } \\
\text { with organic } \\
\text { products }\end{array}$} & $\begin{array}{l}\text { Banana farmers use organic } \\
\text { fertilizers such as chicken } \\
\text { manure, growing worms, } \\
\text { compost, manure, or green } \\
\text { manures such as legumes }\end{array}$ & High & $95 \%$ \\
\hline & $\begin{array}{l}\text { Increase the time between } \\
\text { organic fertilizer application and } \\
\text { harvest to reduce the risk of } \\
\text { contaminating the fruit }\end{array}$ & Low & $10 \%$ \\
\hline $\begin{array}{c}\text { Choice of } \\
\text { plant material }\end{array}$ & $\begin{array}{l}\text { The origin of the plant material } \\
\text { should be taken into account } \\
\text { when selecting seeds, } \\
\text { choosing the characteristics of } \\
\text { growth and vigorous young plants }\end{array}$ & Low & $38 \%$ \\
\hline
\end{tabular}




\begin{tabular}{|c|c|c|c|}
\hline & $\begin{array}{l}\text { The presence of pests and diseases } \\
\text { will decrease dramatically with } \\
\text { these preparation practices. } \\
\text { However, their total elimination } \\
\text { is not guaranteed so it is advisable } \\
\text { to soak the plants in hot water } \\
\text { for a while and apply fungicides } \\
\text { and organic insecticides. }\end{array}$ & High & $75 \%$ \\
\hline \multirow{3}{*}{$\begin{array}{c}\text { Pest } \\
\text { management }\end{array}$} & $\begin{array}{l}\text { Use biological and } \\
\text { mechanical pest management }\end{array}$ & Mean & $50 \%$ \\
\hline & Trap use & Low & $15 \%$ \\
\hline & Biopesticides use & High & $80 \%$ \\
\hline
\end{tabular}

The study showed that the most used agricultural practices were crop associations, the mechanical destruction of diseased plants, the installation of banana and plantain plantations in lowlands, crop rotation, the use of composts and manures to fertilize the soil. The majority of these agricultural practices are agroecological practices with very little use of chemicals. Many banana and plantain farmers use organic farming practices and their cropping systems are likely to be converted to organic production systems. These good organic farming practices contribute to the sustainability of banana production systems and improve the productivity and profitability of the value chain [23]. This is very relevant and shows the potential of bananas and plantains value chain potential to be converted into organic production with many ecological and social economic opportunities.

Results also showed that almost all of the farmers surveyed knew the symptoms of Banana Bunchy Top Disease (BBTD). Only farmers in the Atlantic and Mono do not know the methods of managing this disease showing that they have not received training on best practices for managing BBTD. In this study, the identification of symptoms of BBTD is based on direct observations and not modern technologies using aerial images and machine learning methods [24]. Farmers in Ouémé and Plateau have received several pieces of training on the management of this disease and some producers still use glyphosate, Sharp 480 and Lagon to control it. Raising awareness and training farmers on agroecological methods such as roguing developed in previous studies [25] are essential to better control this disease in bananas. Banana weevil and nematodes are also identified as the major pests of bananas in the study area, but farmers use many agroecological practices (neem oils, trap plants, etc.) for their sustainable management. Other studies showed that the incorporation around the plant base of powdered neem (Azadirachta indica A. Juss.) seed or cake at $60-100 \mathrm{~g} / \mathrm{mat}$ at 4-month intervals, gave better control of the banana weevil, Cosmopolites sordidus (Germar), and parasitic nematodes, than that achieved with soil application of Furadan 5G (carbofuran) at $60 \mathrm{~g} /$ mat at 6-month intervals [26] [27]. 
Several constraints limit the production of bananas and plantains. The majority of these stresses were the effects of climate change, the premature fall of banana plants due to lack of water and damage from diseases and pests. Climate change, diseases and pests weaken the production systems of bananas and plantains [28]. These constraints have been identified in other studies as the main constraints in banana and plantain production [29]. Other constraints such as those of commercialization have been identified. It's about the low selling price and access to markets. This study allowed us to understand the banana and plantain production systems and the challenges to be met for an improvement of their value chain.

\section{Acknowledgements}

This work was funded by Ecological Organic Agriculture. We thank banana and plantain farmers of Southern Benin who unconditionally accepted to respond to interviews and to make available their fields for observations.

\section{Conflicts of Interest}

The authors declare no conflicts of interest regarding the publication of this paper.

\section{References}

[1] Tossou, C.C., Floquet, A.B. and Sinsin, B.A. (2012) Relation entre la production et la consommation des fruits cultivés sur le plateau d'Allada au sud du Benin. Fruits, 67, 3-12. https://doi.org/10.1051/fruits/2011061

[2] Chabi, M.C., Dassou, A.G., Dossou-Aminon, I., Ogouchoro, D., Aman, B.O. and Dansi, A. (2018) Banana and Plantain Production Systems in Benin: Ethnobotanical Investigation, Varietal Diversity, Pests, and Implications for Better Production. Journal of Ethnobiology and Ethnomedicine, 14, 78. https://doi.org/10.1186/s13002-018-0280-1

[3] Ahohouendo, F.A., Togbe, C.E., Agbovoedo, F.R. and Ahohuendo, B.C. (2020) Farmers' Knowledge, Perceptions and Management of Black Sigatoka in Small Plantain-Based Farms in Southern Benin. American Journal of Life Sciences, 8, 172-182. https://doi.org/10.11648/j.ajls.20200805.23

[4] Wairegi, L.W., van Asten, P.J., Tenywa, M.M. and Bekunda, M.A. (2010) Abiotic Constraints Override Biotic Constraints in East African Highland Banana Systems. Field Crops Research, 117, 146-153. https://doi.org/10.1016/j.fcr.2010.02.010

[5] Saxena, R.C. (2014) Neem for Sustainable Pest Management and Environmental Conservation. Chief Editor, 15, 15-31.

[6] Tenywa, M.M., Isabirye, M.I., Lal, R., Lufafa, A. and Achan, P. (1999) Cultural Practices and Production Constraints in Smallholder Banana-Based Cropping Systems of Uganda's Lake Victoria Basin. African Crop Science Journal, 7, 541-550. https://doi.org/10.4314/acsj.v7i4.27756

[7] Waseem, R., Mwalupaso, G.E., Waseem, F., Khan, H., Panhwar, G.M. and Shi, Y. (2020) Adoption of Sustainable Agriculture Practices in Banana Farm Production: A Study from the Sindh Region of Pakistan. International Journal of Environmental 
Research and Public Health, 17, 3714. https://doi.org/10.3390/ijerph17103714

[8] Okonya, J.S., Ocimati, W., Nduwayezu, A., Kantungeko, D., Niko, N., Blomme, G. and Kroschel, J. (2019) Farmer Reported Pest and Disease Impacts on Root, Tuber, and Banana Crops and Livelihoods in Rwanda and Burundi. Sustainability, 11, 1592. https://doi.org/10.3390/su11061592

[9] Damour, G., Garnier, E., Navas, M.L., Dorel, M. and Risede, J.M. (2015) Using Functional Traits to Assess the Services Provided by Cover Plants: A Review of Potentialities in Banana Cropping Systems. In: Advances in Agronomy, Vol. 134, Academic Press, Cambridge, 81-133. https://doi.org/10.1016/bs.agron.2015.06.004

[10] Djigal, D., Chabrier, C., Duyck, P.F., Achard, R., Quénéhervé, P. and Tixier, P. (2012) Cover Crops Alter the Soil Nematode Food Web in Banana Agroecosystems. Soil Biology and Biochemistry, 48, 142-150. https://doi.org/10.1016/j.soilbio.2012.01.026

[11] Dassou, A.G., Carval, D., Dépigny, S., Fansi, G. and Tixier, P. (2015) Ant Abundance and Cosmopolites sordidus Damage in Plantain Fields as Affected by Intercropping. Biological Control, 81, 51-57. https://doi.org/10.1016/j.biocontrol.2014.11.008

[12] Dassou, A.G., Dépigny, S., Canard, E., Vinatier, F., Carval, D. and Tixier, P. (2016) Contrasting Effects of Plant Diversity across Arthropod Trophic Groups in Plantain-Based Agroecosystems. Basic and Applied Ecology, 17, 11-20. https://doi.org/10.1016/j.baae.2015.09.003

[13] Dassou, A.G., Tixier, P., Dépigny, S. and Carval, D. (2017) Vegetation Structure of Plantain-Based Agrosystems Determines Numerical Dominance in Community of Ground-Dwelling Ants. PeerJ, 5, e3917. https://doi.org/10.7717/peerj.3917

[14] Carval, D., Resmond, R., Achard, R. and Tixier, P. (2016) Cover Cropping Reduces the Abundance of the Banana Weevil Cosmopolites sordidus But Does Not Reduce Its Damage to the Banana Plants. Biological Control, 99, 14-18. https://doi.org/10.1016/j.biocontrol.2016.04.004

[15] Lefranc, L.M., Lescot, T., Staver, C., Kwa, M., Michel, I., Nkapnang, I. and Temple, L. (2008) Macropropagation as an Innovative Technology: Lessons and Observations from Projects in Cameroon. IV International Symposium on Banana: International Conference on Banana and Plantain in Africa: Harnessing International, Vol. 879, 727-733. https://doi.org/10.17660/ActaHortic.2010.879.78

[16] Tatsegouock, R.N., Ewané, C.A., Meshuneke, A. and Boudjeko, T. (2020) Plantain Bananas PIF Seedlings Treatment with Liquid Extracts of Tithonia diversifolia Induces Resistance to Black Sigatoka Disease. American Journal of Plant Sciences, 11, 653-671. https://doi.org/10.4236/ajps.2020.115049

[17] Viljoen, A., Mahuku, G., Massawe, C., Ssali, R.T., Kimunye, J., Mostert, D., Ndayihanzamaso, P. and Coyne, D. (2017) Banana Diseases and Pests: Field Guide for Diagnostics and Data Collection. International Institute of Tropical Agriculture (IITA), Nairobi, $73 \mathrm{p}$.

[18] Almadhoun, H.R. and Abu Naser, S.S. (2018) Banana Knowledge Based System Diagnosis and Treatment. International Journal of Academic Pedagogical Research, 2 , 1-11.

[19] R Development Core Team (2014) R: A Language and Environment for Statistical Computing Computer Program. Version by R Development Core Team, Vienna.

[20] Koua, T.C.M., Kone, T., Toure, T. and Kone, M. (2019) Typology of Nurseries and Adoption's Level of the Technique of Plants Derived Stem Fragment "PIF" for the 
Production of Plantain Planting Material (Musa spp.) in Côte d'Ivoire. International Journal of Environment, Agriculture and Biotechnology, 4, 220-228. https://doi.org/10.22161/ijeab/4.1.33

[21] Fainou, M., Ewedje, E.E.B., Adeoti, K., Djedatin, G.L., Affokpon, A., Farid, B.M. and Toukourou, F. (2018) Diversity of Local Varieties of Banana and Plantain Cultivated in Benin. International Journal of Biodiversity and Conservation, 10, 497-509. https://doi.org/10.5897/IJBC2018.1232

[22] Mustaffa, M.M. and Kumar, V. (2012) Banana Production and Productivity Enhancement through Spatial, Water and Nutrient Management. Journal of Horticultural Sciences, 7, 1-28.

[23] Bellamy, A.S. (2013) Banana Production Systems: Identification of Alternative Systems for More Sustainable Production. Ambio, 42, 334-343.

https://doi.org/10.1007/s13280-012-0341-y

[24] Selvaraj, M.G., Vergara, A., Montenegro, F., Ruiz, H.A., Safari, N., Raymaekers, D., Walter, A., Ntamwira, J., Omondi-Aman, B. and Blomme, G. (2020) Detection of Banana Plants and Their Major Diseases through Aerial Images and Machine Learning Methods: A Case Study in DR Congo and Republic of Benin. ISPRS Journal of Photogrammetry and Remote Sensing, 169, 110-124.

https://doi.org/10.1016/j.isprsjprs.2020.08.025

[25] Abiola, A., Zandjanakou-Tachin, M., Aoudji, K.N.A., Avocevou-Ayisso, C. and Kumar, P.L. (2020) Adoption of Roguing to Contain Banana Bunchy Top Disease in South-East Bénin: Role of Farmers' Knowledge and Perception. International Journal of Fruit Science, 20, 720-736. https://doi.org/10.1080/15538362.2019.1673277

[26] Musabyimana, T., Saxena, R.C., Kairu, E.W., Ogol, C.K.P.O. and Khan, Z.R. (2000) Powdered Neem Seed and Cake for Management of the Banana Weevil, Cosmopolites sordidus, and Parasitic Nematodes. Phytoparasitica, 28, 321. https://doi.org/10.1007/BF02981827

[27] Kosma, P., Ambang, Z., Begoude, B.A.D., Ten Hoopen, G.M., Kuaté, J. and Akoa, A. (2011) Assessment of Nematicidal Properties and Phytochemical Screening of Neem Seed Formulations Using Radopholus similis, Parasitic Nematode of Plantain in Cameroon. Crop Protection, 30, 733-738. https://doi.org/10.1016/j.cropro.2011.02.026

[28] Ramirez, J., Jarvis, A., Van den Bergh, I., Staver, C. and Turner, D. (2011) Changing Climates: Effects on Growing Conditions for Banana and Plantain (Musa spp.) and Possible Responses. Crop Adaptation to Climate Change, 19, 426-438. https://doi.org/10.1002/9780470960929.ch29

[29] Schill, P.F., Afreh-Nuamah, K., Gold, C.S. and Green, K.R. (2000) Farmers' Perceptions of Constraints to Plantain Production in Ghana. The International Journal of Sustainable Development \& World Ecology, 7, 12-24.

https://doi.org/10.1080/13504500009470025 